\title{
Cultural motives affecting tea purchase behavior under two usage situations in China: a study of renqing, mianzi, collectivism, and man-nature unity culture
}

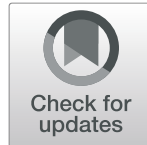

Lingyun Tong ${ }^{1}$, Anne Toppinen ${ }^{1}$ and Lei Wang ${ }^{2 *}$

\begin{abstract}
Tea should be perceived more as a cultural product than a fast-moving consumer good with its roots deep in different cultures across nations. Nevertheless, consumer demands on tea have not been explored sufficiently from a cultural perspective. This research aims to examine motives that are driving Chinese tea consumption on two usage occasions, under the influence of the Chinese renging, mianzi, collectivism, and man-nature unity culture. Linkage was established between Chinese culture and consumer motives. The factor analysis on 280 respondents identified five consumer psychological motives. Further logistic regression analysis suggested consumer motives and usage situations were related. The contribution of the findings is summarized. On one hand, this study adds to the limited understandings on consumer motives of tea in an emerging country from the cultural aspect. On the other hand, deep understandings of brand chasing, sustainability, and pragmatism motives should businesses to better serve consumers.
\end{abstract}

Keywords: Tea, Culture, Purchase behavior, Usage situations

\section{Introduction}

Usage situation (or consumption situation) suggests the anticipated usage and product attributes for one product [1]. For instance, people may choose an unusual brand of coffee for their dinner guests. It is a critical element of the situational factor in the marketing context that can influence purchase decisions and choice of products $[1,2]$. While the usage situation, arguably the most influential in predicting consumer behavior, has strong implications for the market segmentation and niche markets identification, it has received limited attentions in consumer studies $[1,2]$. Besides, issues concerning the expansibility of results remain to be answered, because most studies concerning usage situations have not been examined outside of Western culture (e.g., [1]),

\footnotetext{
*Correspondence: wanglei@zafu.edu.cn

${ }^{2}$ College of Economics and Management, Zhejiang A\&F University, Hangzhou, China

Full list of author information is available at the end of the article
}

while culture difference is critical for marketing strategy. Consumer orientation has long been neglected in lessdeveloped countries [3], even when some of these lessdeveloped countries have shown strong market potentials. Hence, the first intention of this research is to explore the usage situation outside of Western culture.

Tea is consumed by a much wider population in the world now. While tea is sometimes perceived as a readyto-drink product with lower value added [4], it has rich social and culture values. As a non-timber forest product, tea is of great importance to the livelihood of rural tea farmers especially in large tea export countries, including Sri Lanka, Kenya, China, and India (ibid). More importantly, the tea-drinking behavior discloses cultural and social characteristics rather than just for quenching thirst [5]. In fact, in the presence of tea bags or loose tea leaves, tea is more than an industrial product, because it has constituted part of the culture in many countries [6, 7]. Therefore, the marketing of it should also have the

(c) The Author(s). 2021 Open Access This article is licensed under a Creative Commons Attribution 4.0 International License, which permits use, sharing, adaptation, distribution and reproduction in any medium or format, as long as you give

appropriate credit to the original author(s) and the source, provide a link to the Creative Commons licence, and indicate if changes were made. The images or other third party material in this article are included in the article's Creative Commons licence, unless indicated otherwise in a credit line to the material. If material is not included in the article's Creative Commons licence and your intended use is not permitted by statutory regulation or exceeds the permitted use, you will need to obtain permission directly from the copyright holder. To view a copy of this licence, visit http://creativecommons.org/licenses/by/4.0/. 
right understandings of its value [8]. Yet, only a handful of researches exploring consumer behavior of tea, with many focusing on tea's functional value [9-11] and consumers' social demographic characteristics [12-14]. Seldom has consumption culture of tea been mentioned. The marketing strategy of tea should be seen from a rich cultural background, different from that of industrial products.

Of all tea consumption nations, China, where tea originated [15], is an interesting tea market to examine. Despite its long tea history which can date back to the time of Shen Nung (2737 BC) [16], the consumption of tea per capita in China is much lower than that in many other nations, such as Turkey and the UK. It is interesting to examine the tea consumers and their purchase behavior under this circumstance. More importantly, to understand the growth of tea consumption in a culture-rich market, it is not enough to ask what people purchase and who are purchasing (demographic variables), but rather why people purchase and when (for example, usage situations). Hence, the second motivation is to understand the cultural aspects that motivate individuals to consume tea in China.
Overall, the purpose of this research is to examine the motives that drive Chinese consumer purchase decisions under two usage situations, under the influence of the Chinese mianzi, renqing, collectivism, and man-nature unity culture. The whole discussion is organized as follows. Firstly, a careful examination of consumer motives derived from Chinese tea background and Chinese culture is introduced. Secondly, this article will present the research framework and hypotheses. Then, data collection and interview design will be explained before factor analysis and regression analysis. In the end, results and the implications of results are manifested.

\section{Literature review}

\section{History and culture of Chinese tea}

Chinese tea is of various categories subject to classification standards. Differentiated by production methods, there are three major types of tea, the fully fermented black tea, the partially fermented Oolong tea, and the unfermented green tea [17]. Distinguished by the product features, there are over 1000 types of tea from tea-

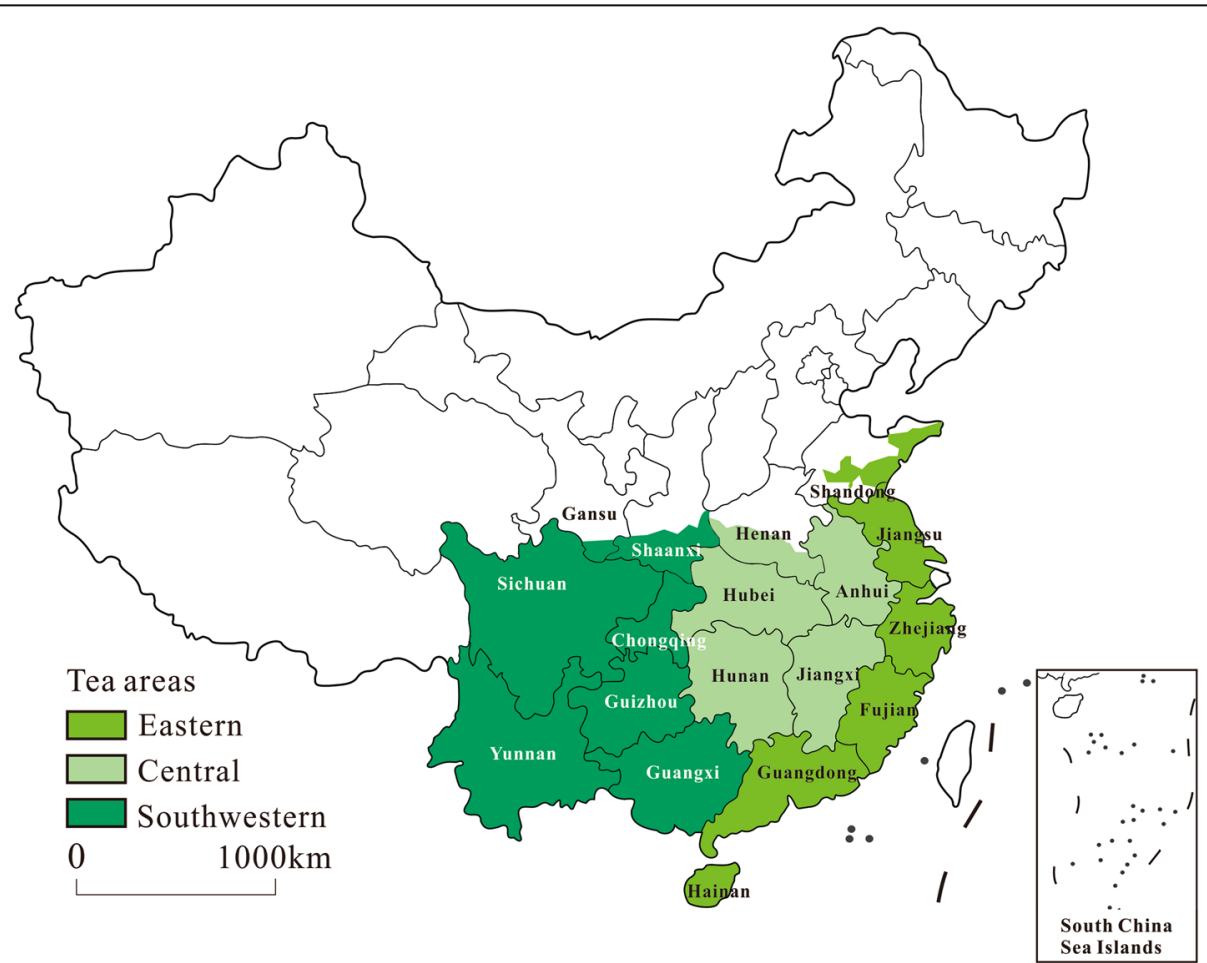

Fig. 1 Map extracted from [18] shows the geometric centers of tea production in the mainland of China. Taiwan province is not discussed due to the data limitation. According to the National Bureau of Statistics of China, tea production regions in the mainland of China consist of eastern, central, and southwestern three parts, a total of 17 provinces and autonomous regions where the weather is warm and damp. Provinces of Shaanxi, Shandong, Gansu, and Henan are not highlighted because tea is only planted partly in these areas. Not all places are suitable to produce the well-known black tea, green tea, and Oolong tea. Instead, each province has its own weather and mountain conditions and produce several unique types of tea. For example, Zhejiang province produce Long-jing green tea and Anji white tea (one of partially fermented tea), and Yunan province is famous for its Yunnan dian hong (one kind of black tea) 
producing provinces across China's mainland (Fig. 1), identified as unique and well-recognized famous tea by the encyclopedia of famous Chinese tea $[18,19]$.

The history of tea in China is long. It is widely believed that tea was initially discovered by Chinese emperor Shen Nung (Divine Husbandman) in 2737 BC (Fig. 2) [17], while the physical evidence of tea suggests that tea was consumed as early as the second century BC by emperor Han Jing (died in 141 BC) [20]. Initially documented as a medicine collected from the wild, tea gradually became a tasty drink among the nobility in the Han dynasty (206 BC to AD 220) and the Three Kingdoms periods (220-280) [21]. During that time, tea of high quality was sent as a tribute from localities to the court annually to show respect to the emperor [22]. Such high-end gift tea is named Gongcha (ibid). Also, the court would send back tea as a special gift to the nomadic people to maintain relationships and its political power [6]. It was not until the Tang dynasty (618-907), during which period, Lu Yu's monograph "The Classic of Tea (Fig. 3)" published and the Buddhism prevailed that tea culture brought a profound social change in Chinese elite culture and that tea became a daily necessity for the Han people [15, 24]. Geographically, tea production and trade first developed from the hilly regions in southern China but later took root in other areas inhabited by Han people, such as Zhejiang province, during Tang and Song dynasties [21, 24].

With its widespread fame across people and countries since the medieval period, tea has gradually been given much political and commercial importance [24]. Along with silk and porcelain, tea is traded as valuable commodities in exchange for horses along the borders of China in Tang and Song (S). The ancient Tea Horse Road, which was developed to the Silk Road later, was

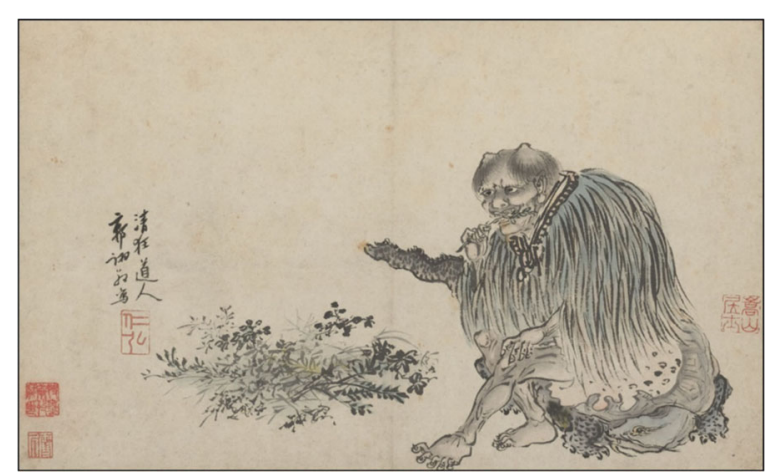

Fig. 2 The portrait of Shen Nung in a fashionable manner as a "wild man" by Guo Xu [6]. Shen Nung is a legendary emperor credited with inventing medicine and discovering tea. The legend says when Shen Nung was boiling water, a few leaves from a wild tree fell into the bowl. Because tea tasted refreshing and cleared his mind, it was first documented as a herbal medicine beverage. The story also suggests that tea has a simple form, the green tea, in the first place

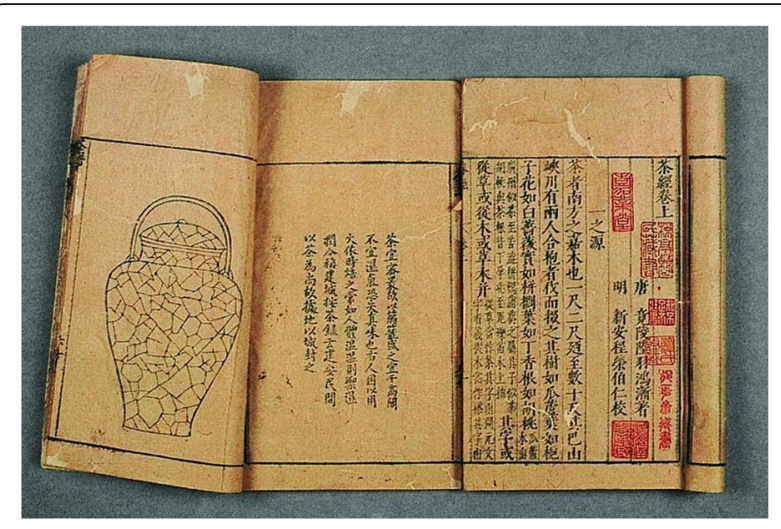

Fig. 3 The picture derived from Chen [23] showed the classic of tea. This book was completed by Lu Yu (733-804) around CE 760. It not only introduces the history and geography of the tea plant, but also provides careful notes on the way to grow the tea plant, process tea leaves, brew, and serve tea. More importantly, the book helps to establish tea as a respected beverage and legitimize tea drinking as a cultural and elegant activity suitable for the elites

created, and the Chinese dynastic government established an official "Tea and Horse Bureaus" (Chamasi) in charge of the tea trade [6, 24]. Gradually through trade, the tea-drinking customs spread over European countries and many other areas in the world and largely enriched the world civilization [24].

In fact, tea consumption has been closely related to social religions and trends [24]. Under Chinese ancient Daoism, the emphasis for tea drinking is on the inner peace of oneself and the sequestered but human-nature harmonized lifestyle $[25,26]$. For Tang Buddhism, tea serves more as a construct towards Zen (deep meditation or one's inner peace) [22, 25]. Confucianism, on the other hand, has developed tea culture further to add positivism (engaging oneself into social and even political life) and Zhongyong (the golden mean of the Confucian school) into tea consumption spirit [22]. Interestingly, as tea connoisseurship became more sophisticated since post-Tang, tea also served to honor one's social identity. Through the sophisticated tea rituals and the use of famous tea as gifts, a man could manifest a superior form of manhood and win respect from others and elevate his social standing $[22,27]$

\section{Consumer motives}

Consumer motives refer to consumer's needs and wants for a product in this article. Needs are inner states aroused by the discomfort of a person's psychological and physical conditions [28]. Wants on the other hand are product-oriented desire which takes a person's current psychological and physical condition beyond the minimal comfort level (ibid). Despite their differences, they together create demands, and such demands are to be met by products. It is argued a product serves as an 
extension of consumers' personalities, and the symbolic meaning of a product may matter more than its functions [29]. Hence, consumer motives are the very targets marketing mixes constructed to respond to and are the base for product position and market segmentation.

Efforts have been made to identify what constitutes consumer motives from different angles. Belk et al. [30], in general, described consumer desires as interpersonal, positive, and cyclic in three countries with different cultural heritage. From a microperspective, with the assumption that consumers own various personalities and mindsets, consumer decision-making styles identify several consumer-style inventories (CSI) [31, 32]. Studies have tested the applicability of CSI in the Chinese environment but did not reach an agreement. For instance, Noel et al. [33] identified brand, novelty and uniqueness chasing, perfectionism, and recreational consciousness in China, while Li et al. [34] assert that confused by over choice, fashion, and impulsive and perfect consciousness are motives for Chinese peasant consumers. Neither has there been CSI literature on Chinese consumers bringing traditional Chinese culture into account.

\section{Consumer motives from Chinese culture}

Hofstede [35] argues for the importance of taking culture into account when examining consumer behaviors in different nations. Therefore, it is essential to involve Chinese culture, namely the traditional values and thoughts, to better understand Chinese consumer motives. In the past, researcher has found influences of culture on consumer motives mixed [36, 37]. Under this section, consumer motives to be examined are concentrated on renqing and mianzi, collectivism, and mannature unity three components.

\section{Motives from reqing and mianzi}

Renqing and mianzi are two important elements coming from social interactions in Chinese culture [38]. Renqing, a synonym for guanxi (relationship), indicates a set of social obligations that require maintaining contact with people in their social network and participating in exchanging gifts in the form of goods, services, money, or information [39]. It suggests the perceived importance of reciprocity among the Chinese. Mianzi refers to an individual's perception of their public image, which is earned by performing their social role and recognized by others [40]. It is the manhood that individuals claim for themselves through their networks at their social position. The degree to which they receive judgment is based on the adequacy and acceptability of their conduct as perceived by others [41].

Although the notion of face may seem similar to the Western concept of dignity [40], renqing and mianzi are much more influential socially among Confucian societies, as Chinese consumers are more likely to chase higher brands with high visibility to save face on social occasions [38]. The motive to enhance one's social hierarchy and power or to signal self-prestige and status is named chasing brand and prestige motive here. In fact, this motive is found prevalent in luxury goods purchase context, describe as face consumption or conspicuous consumption (e.g., [42-44]). On the contrary, consumer motives to pursue more quality and value over price are classified as pragmatism in this study. Studies also identify such motive, called chasing value in money or rational buyer, among modern Chinese consumers [33, 45].

\section{Motives from collectivism and individualism}

While the people in the West are more individualistic, Chinese has been found to be collectivistic [35, 46]. Collectivism is a critical trait of Confucianism which focuses on social order and hierarchy [22]. Collectivists tend to have a strong desire for recognition in their network via conforming to the social order and common practice $[35,47]$. For collectivists, they think highly of public perceptions and rely on evaluations from others and group norms. As a result, individuals often seek views of leaders and tradition norms and sacrifice personal independence. Such motive is named the conformity here, while other studies label it with opinion seeker $[43,45]$.

On the contrary, individualism focuses on oneself as an autonomous person and inspires people to make decisions based on their own thinking [35]. As a consequence of China economic reforms and modernization, the old Confucian ideology and collectivism have been challenged with individualism. It is argued that Chinese consumers, especially the younger generations, have become more self-aware and seek fun and unique experience [48]. As a typical aspect of individualism, novelty and uniqueness chasing motive is introduced here to exhibit the paradoxical consumer behavior motives. In fact, this motive has been confirmed among Chinese consumers $[33,34]$.

\section{Motives from the unity of man and nature}

Sustainability awareness exists when consumers exhibit ecological concern, understand the importance of environmental protection, and try to replace high-impact goods with environmentally benign products [49]. For the purpose of this study, it is defined as a motive pursuing healthy lifestyle and active in achieving environmental sustainability. The modern idea of the sustainable use of natural resources and environment protection can be found in the tea culture under the influence of Sinitic Daoism (since $142 \mathrm{CE}$ ) and Confucianism [50]. They assert that man should respect the intrinsic means of nature (ziran), respect the boundaries of nature, and avoid exploiting the nature resources $[50,51]$. Ancient Daoist 
Zhuangzi put forward the "trinity of heaven, man, and earth" or the unity of nature and man (tianren heyi), suggesting that the heaven and the earth are a single body and the world is one family (ibid). Confucians also respected appropriate boundaries and limits of nature and considered man harmonizing with nature [51].

When it comes to tea, one is expected to drink with his inner peace and to live a human-nature harmonized life $[25,26]$. It is believed that tea drinkers' moral quality, tea's quality [, and the external environment should harmonize $[16,17]$. Such relation with the environment was more a harmony "trinity of heaven, man, and earth" rather than a competition [52], which is in line with the modern concept of sustainability [53, 54]. Although the man and nature unity in Sinitic philosophy did not prevent China from environmental deterioration [51], religion, and other core values still serve as an autonomous motive embedded into Chinese daily life [55].

\section{Theoretical framework: effects of consumer motives on purchase purpose}

Effects of brand, prestige chasing, and pragmatic motives Social behavior, including gift giving in China, is arguably influenced by brand and prestige chasing motive as a result of renqing and mianzi $[39,56]$. For example, gifts on social occasions not only symbolize the intentions and images of givers, but also symbolize respect felt for receivers, especially when they turn into an instrument to save and maintain face [40, 43]. The amount paid, the brand, and the importance attached to the products are particularly different [57]. Willingness to pay for an item can be higher in such circumstances than the ordinary self-use level to save one's own mianzi and to care for others' feelings and faces. On the opposite, tea purchase for self-use purposes appears more related to value at price. Hence, we hypothesize the following (as Fig. 4 shows):

1) Tea purchase for social use purposes is positively affected by brand and prestige chasing motives.

2) Tea purchase for self-use purposes is positively affected by pragmatism motive.

Effects of confirmatory, novelty, and uniqueness chasing motives

Conformity motive, driven by collectivism, can arguably influence people's social behaviors. In social situations, conformity is likely to exert more impacts on Chinese consumer behaviors, since the purchase choice Chinese consumers make is ethically bounded to meet the social standards [47]. Friends and parents are argued to be important references in one's social purpose-driven consumption behavior [58]. On the contrary, the novelty and uniqueness chasing motive, as a typical individualistic characteristic, can influence Chinese's selfconsumption products, when people are less bounded to choose a product to meet others' requirement [48]. Hence, we hypothesize the following (as Fig. 4 shows):

1) Tea purchase for social use purposes is positively affected by conformity motive.

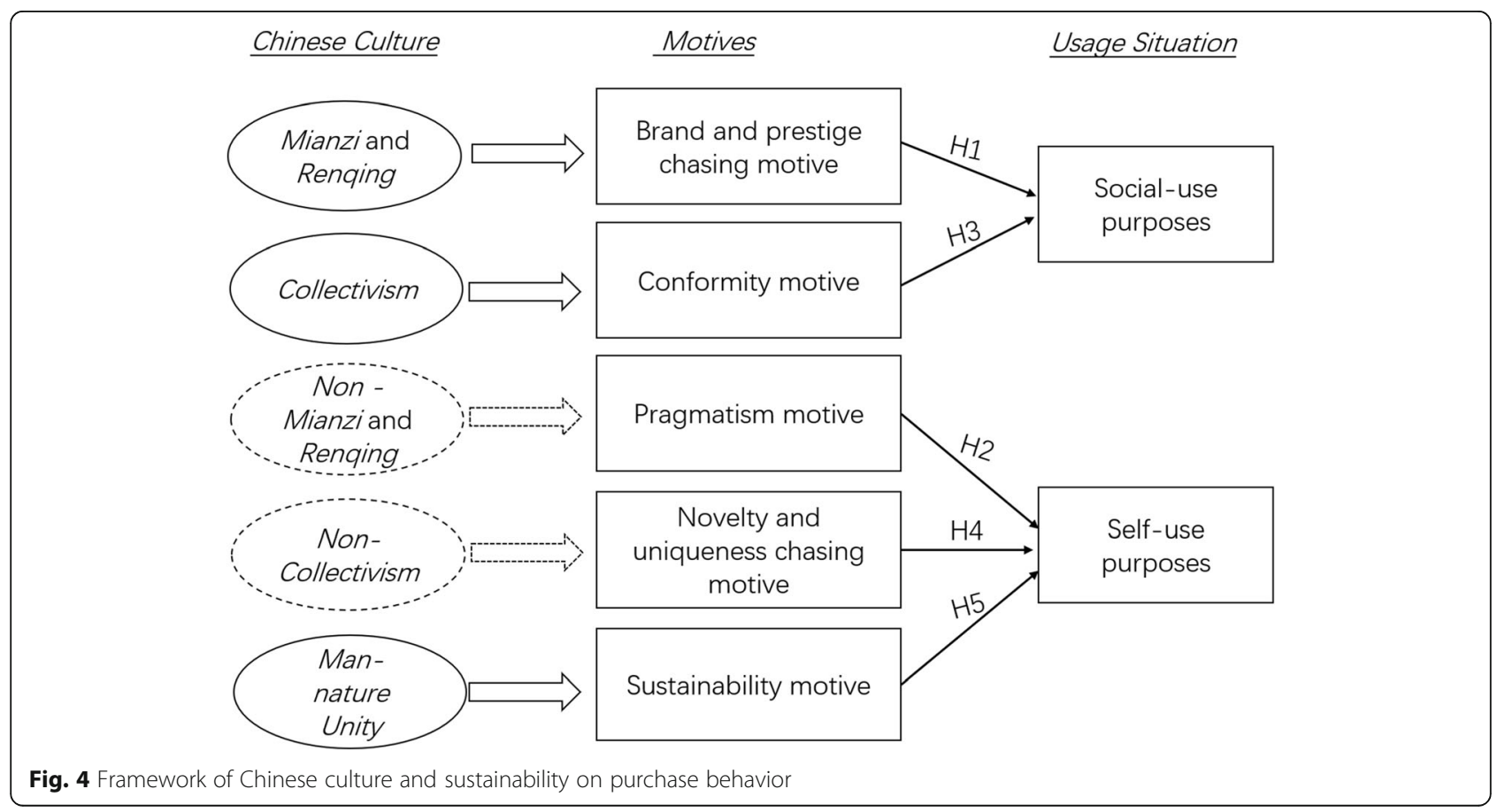


2) Tea purchase for self-use purposes is positively affected by novelty and uniqueness chasing motives.

\section{Effects of sustainable motives}

Research has found that sustainability awareness is provoked by personal feelings, associated with self-image expression and emotional value, and certain Chinese are emotionally attached to environmental issues and consider green purchasing their moral responsibility [59]. Some Chinese experience positive feelings from safe-guarding the environment and doing good for the society [60]. Tai [45] and Wan and Toppinen [61] also denotes that sustainable awareness exists at individual levels as they prefer a healthy lifestyle. Hence, we hypothesize that (as Fig. 4 shows) tea purchase for selfuse purposes is positively affected by sustainable motive.

\section{Methodology}

\section{Research design}

To test the proposed hypothesis, we collected data from face-to-face structured interviews. We first explored the dimensionality of the proposed tea consumer motives. Factor analysis was performed using Varimax rotation with eigenvalues greater than 1 . Second, to identify the determinants of the tea purchasing behavior under two usage conditions (self-use and social use), log-binomial regression analysis was adopted. The goal of regression analysis was to test the proposed hypothesis by identifying whether motives $\left(X_{i}\right)$ were statistically significant to the purchase behavior for either self-use or social-use purposes. The nature of the log-binomial model would suggest the likelihood of the occurrence of either tea purchase for self-consumption or tea purchase for social purposes.

$$
\ln \frac{p}{1-p}=\operatorname{Logit}(P)=a+b_{1} X_{1}+b_{2} X_{2}+\ldots+b_{i} X_{i}+e, \text { for } i=1 \ldots 5
$$

where $p$ is usage situation for self-use, and $1-p$ is usage situation for social use.

\section{Interview design}

The questionnaire first asked consumers to recall their most recent purchase situation of loose leaf tea or bagged tea, whether the purchase was for social use or for self-use. Each of the proposed motive attributes was presented with several (at least three) attribute-related questions. All attributes were measured by a 5 -point Likert scale to investigate the interviewees' level of agreement or disagreement. Back translation was adopted when preparing the questionnaires, in which three bilingual individuals translated items from Chinese to English and then back into Chinese. Five Chinese students and two professors reviewed the translations, so as to minimize colloquial and idiomatic wording issues. In addition, demographic variables were added into the last section of the interview, including gender, place of birth, age, ethnic group, education background, occupation, and household monthly income.

\section{Data collection}

Zhejiang province was chosen for the interview because of its fame as the major tea production region, its large and growing population base, rapid economic growth, and increasing consumer purchasing power in the past few decades [62]. Three cities (Hanghou, Jiaxing, and Ningbo) presenting major economic positions in Zhejiang were selected for data collection. Particularly, the capital city of Zhejiang, Hangzhou, famous for its Xihu Longjing tea, is perceived as a rapidly developing city with increasing consumer purchasing power, therefore serving as a good indicator for future consumer purchasing patterns in China at large. We interviewed Chinese consumers in shopping centers and in tea houses, focusing on adults (over 18-year-olds) to mirror the true tea consumer population. A total of 319 filled out questionnaires were sent out and finished by interviews, of which 280 were finally retained with careful examination. A summary of the socio-demographic characteristics of these 280 respondents is presented in Table 1.

\section{Results}

The reliability of the factor analysis on consumer movies is shown reliable, as Table 2 shows Cronbach's $\alpha$ (0.726), KMO (0.808), eigenvalues exceeding 1 , Bartlett's test giving a significant result $(P$ value $<0.05)$. Factor analysis suggests that a solution with five key motive dimensions is reckoned to be most logical, that is sustainable, brand and prestige chasing, social confirmatory, novelty and uniqueness chasing, and pragmatic motives. This solution captures $60.7 \%$ of the total variance associated with the dependent variable (Nagelkerke $R^{2}=0.602$, Cox and Snell $R^{2}=0.450$ ). The Ominibus tests show that the entire logistic model is significant at the 0.0001 level.

As shown in Table 3, the results of logistic regression reveal that three out of five motives are significant at 0.05 significant level. Motives of sustainability $(p=0.039)$ and pragmatism $(p=0.000)$ are proved positively associated with the purchase for self-use purposes, while motive of brand and prestige chasing $(p=0.000)$ positively associated with the purchase for social use purposes. The motive of novelty and uniqueness $(p=$ 0.0509 ) is also positively associated with the purchase for self-use purposes at close to $95 \%$ confidence interval. With a larger sample size, this relation is more likely to be more significant. Lastly, the motive of conformity is also shown to be positively associated with the 
Table 1 Demographic profile of the respondents $(N=280)$

\begin{tabular}{|c|c|c|}
\hline Demographic characteristics & Frequency & $\begin{array}{l}\text { Percentage } \\
(\%)\end{array}$ \\
\hline \multicolumn{3}{|l|}{ Gender } \\
\hline Male & 136 & 48.6 \\
\hline Female & 144 & 51.4 \\
\hline \multicolumn{3}{|l|}{ Place of birth } \\
\hline Northern China & 46 & 16.4 \\
\hline Eastern China & 98 & 35.0 \\
\hline Southern China & 106 & 37.9 \\
\hline Western China & 5 & 1.8 \\
\hline Central China & 25 & 8.9 \\
\hline \multicolumn{3}{|l|}{ Age } \\
\hline $18-24$ & 56 & 20.0 \\
\hline $25-34$ & 91 & 32.5 \\
\hline $35-44$ & 94 & 33.6 \\
\hline $45-54$ & 26 & 9.3 \\
\hline $55-64$ & 9 & 3.2 \\
\hline $65+$ & 4 & 1.4 \\
\hline \multicolumn{3}{|l|}{ Ethnic group } \\
\hline Han & 266 & 95.0 \\
\hline Minority group & 14 & 5.0 \\
\hline \multicolumn{3}{|l|}{ Education background } \\
\hline Below high school graduate & 70 & 25.0 \\
\hline High school degree & 8 & 2.9 \\
\hline Bachelor's degree & 148 & 52.9 \\
\hline Master's degree & 43 & 15.4 \\
\hline Ph.D. and above & 11 & 3.9 \\
\hline \multicolumn{3}{|l|}{ Occupation } \\
\hline Civil servants and diplomats & 23 & 8.2 \\
\hline $\begin{array}{l}\text { Professional (educator, engineering, IT, } \\
\text { doctor, nurse, lawyer, consultant, athletes) }\end{array}$ & 98 & 35.0 \\
\hline General business clerk & 76 & 27.1 \\
\hline Corporate management & 32 & 11.4 \\
\hline $\begin{array}{l}\text { Artists (e.g., producer, actor, director, } \\
\text { designer) }\end{array}$ & 7 & 2.5 \\
\hline Self-employed & 2 & 0.7 \\
\hline Farmer & 1 & 0.4 \\
\hline Others & 41 & 14.6 \\
\hline \multicolumn{3}{|l|}{ Household monthly income (RMB) } \\
\hline Up to 3499 & 26 & 9.3 \\
\hline $3500-7499$ & 102 & 36.4 \\
\hline $7500-12499$ & 82 & 29.3 \\
\hline $12500-16499$ & 39 & 13.9 \\
\hline More than 16500 & 31 & 11.1 \\
\hline
\end{tabular}

purchase for self-use situation $(p=0.77)$, but the association is not statistically significant at 0.05 significance level. Hence, the empirical results of this study give strong supports to $\mathrm{H} 1, \mathrm{H} 2$, and $\mathrm{H} 5$ and render preliminary substantiate to the direction of the relationship in $\mathrm{H} 3 \mathrm{H}$. $\mathrm{is}$ not statistically significant at the 0.05 significance level.

\section{Discussion}

\section{General discussion of results}

Results of brand and prestige chasing motives $(\beta=6.74)$ described a positive relationship with the purchase for social-use purposes. The odds of purchasing for social and gift purposes of consumers motived by brand and prestige chasing is 6.74 times greater than that for the self-use situation. While previous literatures connect brand and prestige chasing motives with Chinese luxury consumption and out-shopping (such as [44]), the results of this study show that brand and prestige chasing motive also has effects on ordinary goods consumption, such as tea, for Chinese or possibly people under Confucian's mianzi and renqing influence during social situations. This finding is in line with the results of Wang et al. [44] that the Chinese choose branded tea as gifts to save faces for both givers and receivers. This motive is not the same in the Western culture, where brand choice serves more as a way of self-expression [63]. On the other hand, the results of pragmatic motive $(\beta=0.24)$ suggested a positive relationship between pragmatism with the purchase for self-use purposes. That is, the Chinese tend to be practical for self-usage products, focusing on value in price, regardless of brand names.

This study further reveals that sustainability has been an important motive for tea purchase. The sustainability consciousness $(\beta=-0.36)$ has shown a positive relationship with tea purchases for self-consumption purpose. It suggests that the Sinitic man-nature harmony philosophy still lasts in people's mind in Zhejiang province if not all provinces in China, in spite of the assentation that Chinese industrialization and modernization processes have excelled the nature protection [50]. This is consistent with the arguments of Chan and Lau [51].

On top of that, the novelty and uniqueness chasing motives show a minor positive influence on self-usage purchase occasions $(p=0.0509)$. This minor effect may due to the unsufficient sample size and limited region being studied, as the Zhejiang market is relatively more liberalized. Further studies can expand the region of research and increase the volume of surveys to check again this result. The conformity motive is far from being significantly associated with the self-usage situation at a 0.05 significance level. One possible explanation is that consumers do not need more references during tea 
Table 2 Factor analysis of consumer tea purchase

\begin{tabular}{|c|c|c|c|}
\hline Factor & Factor loading & Eigenvalue & $\begin{array}{l}\text { Accum. variance } \\
\text { explained (\%) }\end{array}$ \\
\hline Factor 1: sustainability (SUS) & & 4.4 & 21.8 \\
\hline Prefer biodegradable and reusable products & 0.690 & & \\
\hline Prefer organic food and minimum food additives & 0.699 & & \\
\hline Prefer products with FSC, MSC certification & 0.737 & & \\
\hline Try to reduce carbon footprint during consumption & 0.716 & & \\
\hline Try not to waste nature resources during consumption & 0.662 & & \\
\hline Prefer eco-friendly and sustainable consumption & 0.685 & & \\
\hline Factor 2: brand and prestige chasing (BP) & & 3.6 & 39.5 \\
\hline Prefer branded products despite of limited income & 0.824 & & \\
\hline Prefer prestigious and high-end products & 0.789 & & \\
\hline Desire to show social status through brands & 0.824 & & \\
\hline Prefer brand name than practical value & 0.758 & & \\
\hline Factor 3: pragmatism (PRG) & & 1.7 & 47.8 \\
\hline Always choose what is most needed & 0.689 & & \\
\hline Consider affordability & 0.674 & & \\
\hline $\begin{array}{l}\text { Compare carefully the quality, performance, and value } \\
\text { of products before purchase }\end{array}$ & 0.716 & & \\
\hline Prefer high practical and affordable products & 0.748 & & \\
\hline Factor 4: novelty and uniqueness chasing (NU) & & 1.4 & 54.8 \\
\hline Prefer distinguished products & 0.800 & & \\
\hline Prefer goods with special appearances & 0.751 & & \\
\hline Enjoy the novelty and being different & 0.678 & & \\
\hline Factor 5: social conformity (SC) & & 1.2 & 60.7 \\
\hline Follow recommendations from friends and colleagues & 0.770 & & \\
\hline Prefer similar products possessed by peers & 0.813 & & \\
\hline Follow trends and recommendations from mass media & 0.613 & & \\
\hline
\end{tabular}

Note: (a) Model-Cronbach's $a=0.726, \mathrm{KMO}=.808$, chi-square $=1899.67$, Bartlett's test of sphericity $p<.000$. (b) Factor degree: $1=$ absolutely disagree, $5=$ absolutely agree

shopping when high-end tea brands suitable for social use in Zhejiang, such as Longjing green tea, seem already well-known. Brand and prestige chasing motives may be more dominant during social use occasions.

Table 3 Summary of regression analysis

\begin{tabular}{lllll}
\hline & Coefficient $(\boldsymbol{\lambda})$ & OR $(\boldsymbol{\beta})$ & S.E. & Significance \\
\hline Constant & -0.35 & 0.70 & 0.17 & 0.043 \\
SUS & -0.36 & 0.70 & 0.18 & 0.039 \\
BP & 1.91 & 6.74 & 0.24 & 0.000 \\
PRG & -1.42 & 0.24 & 0.21 & 0.000 \\
NU & -0.13 & 0.88 & 0.19 & 0.509 \\
SC & -0.06 & 0.95 & 0.19 & 0.770 \\
\hline
\end{tabular}

\section{Implications}

The implications of research results two folded. First, this study suggests that consumer motives derived from the local culture and usage situations are related in China, enriching the research of usage situations outside of Western culture $[1,2]$. The study of consumer psychology from a culture perspective would also enrich the limited understandings of tea consumers in one of the biggest tea consumption countries. At the practical level, marketers would benefit from their clear understandings of the culture value of tea when developing a marketing strategy in China. Details and delicacy of products will express their concerns for consumers in different usage occasions. Social use and self-use product lines should be distinguished clearly with different semi-brand names, especially when renqing and mianzi still play a major role in Chinese social use occasions. 
Second, the increase in sustainability awareness among consumers, especially householders, should be noted. It will help advance the green revolution [64], as Grunert [65] explained that 30 to $40 \%$ of environmental degradation resulted from private households' consumption. Responsible tea producers should covey their ecofriendly products to consumers efficiently. Although such sustainability seems to play a minor role during social use occasions, it can be addressed when combined with high-end brands used in a social situation. Thus, a high degree of ecological concerns among individual consumers is channeled to corresponding sustainable and green purchases.

\section{Conclusions}

This research has studied usage situations from a proactive point of view under the Chinese renqing, mianzi, collectivism, and man-nature unity culture. The results of the factor analysis confirmed 5 categories of motives derived from Chinese culture. The regression analysis gives strong supports to $H 1, H 2$, and $H 5$, and renders preliminary substantiate to the direction of the relationship in $H 3$. The motives of brand and prestige chasing are positively related to the social situation, while motives of sustainability, pragmatism and chasing novelty and uniqueness are positively related to consumer purchase under self-use situation. The implications are elaborated. As consumer motives derived from the local culture and usage situations are related, this study suggested that culture value should be addressed by marketers. This study also emphasized the importance of consumer sustainability motives during self-use conditions. Policymakers and markers should make wise decisions to channel these motives to corresponding sustainable consumption behaviors.

Nevertheless, the data set does not prove enough significance of conformity motives under two usage situations, with data collected in Zhejiang province. As a province famous for tea production and consumption with $90 \%$ of interviewees were Han Chinese, it may not represent the whole Chinese population. Hence, further studies can expand the region of research and involve more minority ethnic groups to provide better grounds for research results.

\section{Acknowledgements \\ Many thanks to Dr. Zhang Haibing and Dr. Jaana Korhonen for their methodological help.}

\section{Authors' contributions}

All authors made substantial contributions to the conception and design of the work. TL and WL were responsible for the acquisition of the data and conducting the analysis. TL and AT conducted the interpretation of the data. AT and WL helped to write and edit the manuscript. All authors have drafted the final version of the work with substantial revisions and have approved the submitted version.

\section{Funding}

This study was supported by the National Social Science Foundation of China (Grant No.19BGL174) and the Scientific Research Foundation of Zhejiang A\&F University (No.103-2034020091).

\section{Availability of data and materials}

The data that support the findings of this study are openly available via https://osf.io/c8zxa/?view_only=f55c709f8661478e87b4820335d54043 at DOI: 10.17605/OSF.IO/C8ZXA

\section{Declarations}

\section{Competing interests}

The authors declare that they have no competing interests.

\section{Author details}

${ }^{1}$ Department of Forest Sciences, University of Helsinki, Helsinki, Finland. ${ }^{2}$ College of Economics and Management, Zhejiang A\&F University, Hangzhou, China.

Received: 17 June 2020 Accepted: 22 July 2021

Published online: 10 August 2021

\section{References}

1. Barber N, Dodd T, Ghiselli R. Capturing the younger wine consumer. J Wine Res. 2008;19(2):123-41. https://doi.org/10.1080/09571260802622225.

2. Dodd T, Laverie D, Wilcox J, Duhan D. Differential effects of experience, subjective knowledge, and objective knowledge on sources of information used in consumer wine purchasing. J Hosp Tour Res. 2005;29(1):3-19. https://doi.org/10.1177/1096348004267518.

3. Douglas SP, Craig CS. On improving the conceptual foundations of international marketing research. J Int Mark. 2006;14(1):1-22. https://doi. org/10.1509/jimk.14.1.1.

4. Euromonitor. Global Tea: Consumer Trends Coverage around Brewed Beverages. 2016. Retrieved from https://www.euromonitor.com/global-teaconsumer-trends-converge-around-brewed-beverages/report. Accessed 10 Sep 2019.

5. Wang L. Tea and Chinese culture. San Francisco: Long River Press; 2005. p. 1-9.

6. Sigley G. Tea and China's rise: tea, nationalism and culture in the 21st century. Int Commun Chin Cult. 2015;2(3):319-41. https://doi.org/10.1007/s4 0636-015-0037-7.

7. Yoder AJ. Myth and memory in Russian tea culture. Stud Slavic Cult. 2009;8: 65-89.

8. Liu JC. Between classical and popular: the book of tea and the popularization of tea-drinking culture in the tang China. J Pop Cult. 2011; 44(1):114-33. https://doi.org/10.1111/j.1540-5931.2010.00822.x.

9. Bettuzzi S, Brausi M, Rizzi F, Castagnetti G, Peracchia G, Corti A. Chemoprevention of human prostate cancer by oral administration of green tea catechins in volunteers with high-grade prostate intraepithelial neoplasia: a preliminary report from a one-year proof-of-principle study. Cancer Res. 2006;66(2):1234-40. https://doi.org/10.1158/0008-5472.CAN05-1145.

10. Li F, Wang Y, Li D, Chen Y, Qiao X, Fardous R, et al. Perspectives on the recent developments with green tea polyphenols in drug discovery. Expert Opin Drug Discovery. 2018;13(7):643-60.

11. Mukhtar H, Ahmad N. Tea polyphenols: prevention of cancer and optimizing health. Am J Clin Nutr. 2000;71(6):1698S-702S. https://doi.org/1 0.1093/ajcn/71.6.1698S.

12. Chen $F$, Li S, Jiang $R$, Jiang A. What factors are influencing tea consumption among Chinese urban residents? An empirical study. Int J Consum Stud. 2016;40(2):249-54. https://doi.org/10.1111/ijcs.12249.

13. Ghosh $\mathrm{M}$, Ghosh $\mathrm{A}$. Consumer buying behaviour in relation to consumption of tea - a study of Pune City. Int J Sales Mark. 2013;3(2):47-54.

14. Xu YM. An investigation into the tea consumption behaviors in Tongcheng, Anhui Province of China. Chinese Food and Nutrition. 2017;7:30-2. https:// doi.org/10.3969/j.issn.1006-9577.2007.07.010.

15. Chaffee JW. Tea in China: a religious and cultural history by James A. Benn, and The rise of tea culture in China: the invention of the individual by Bret Hinsch (review). Harv J Asiat Stud. 2017;77(2):493-502 (Review). 
16. Wang N. A comparison of Chinese and British tea culture. Asian Culture and History. 20110;3(2):13.

17. Ho CT, Lin JK, Shahidi F. Tea and tea products: chemistry and healthpromoting properties. Boca Raton: CRC Press; 2008. https://doi.org/10.1201/ 9781420008036

18. Xiao Z, Huang $X$, Zang Z, Yang H. Spatio-temporal variation and the driving forces of tea production in China over the last 30 years. J Geogr Sci. 2018; 28(3):275-90. https://doi.org/10.1007/s11442-018-1472-2.

19. Wang ZH, Wang GZ. Encyclopedia of famous Chinese tea. Beijing: China agriculture Press; 2000. (in Chinese)

20. Lu H, Zhang J, Yang Y, Yang X, Xu B, Yang W, et al. Earliest tea as evidence for one branch of the Silk Road across the Tibetan Plateau. Sci Rep. 2016; 6(1):18955. https://doi.org/10.1038/srep18955.

21. Liu T. Chinese tea. The United States of America: Cambridge University Press; 2012.

22. Hendrischke, Barbara. Tea in china: a religious and cultural history by James A. Benn. Honolulu: University of Hawai'i Press. 2015. Relig Stud Rev. 2016;42(3):225.

23. Chen ZM. Zhongguo Chajing. Shanghai: Shanghai Culture Press; 1992. (in Chinese)

24. Benn JA. Tea in China: a religious and cultural history. Honolulu: University of Hawai'i Press; 2015. p. 303-8. https://doi.org/10.21313/hawaii/978082483 9635.001.0001.

25. Cheng SW, Xu F, Zhang J, Zhang YT. Tourists' attitudes toward tea tourism: a case Study in Xinyang. J Travel Tour Mark. 2010;27(2):211-20. https://doi. org/10.1080/10548401003590526.

26. Ming Ming S, Wall G, Wang Y. Integrating tea and tourism: a sustainable livelihoods approach. J Sustain Tour. 2019;27(10):1591-608. https://doi.org/1 0.1080/09669582.2019.1648482.

27. Hinsch B. The rise of tea culture in China: the invention of the individual: Rowman \& Littlefield Publishers; 2015. p. 131-6.

28. Lamb C Jr, Hair JF Jr, McDaniel C. Marketing. 5th Edition. Cincinnati: SouthWestern College Publishing; 2000

29. Roustasekehravani A, Hamid ABA, Hamid AA. The effect of brand personality and brand satisfaction on brand loyalty: a conceptual paper. J Manag Res. 2015;7(2):10. https://doi.org/10.5296/jmr.v7i2.6924.

30. Belk RW, Ger G, Askegaard S. Consumer Desire in Three Cultures: Results from Projective Research. Adv Consum Res. 1997:24:24-8.

31. Lysonski S, Durvasula S. Consumer decision making styles in retailing: evolution of mindsets and psychological impacts. J Consum Mark. 2013; 30(1):75-87. https://doi.org/10.1108/07363761311290858.

32. Sprotles $G B$, Kendall EL. A methodology for profiling consumers' decisionmaking styles. J Consum Aff. 1986;20(2):267-79. https://doi.org/10.1111/j.174 5-6606.1986.tb00382.x

33. Noel YM, Siu NY, Wang CC, Chang LM, Hui AS. Adapting consumer style inventory to Chinese consumers: a confirmatory factor analysis approach. J Int Consum Mark. 2001;13(2):29-47. https://doi.org/10.1300/J046v13n02_03.

34. Li B, Zhai C, Bao W. An empirical study on the decision making styles of the Chinese peasant consumers. J Consum Mark. 2010;27(7):629-37. https://doi. org/10.1108/07363761011086371

35. Hofstede G. Comparing Values, Behaviours, Institutions and organizations across nations. Thousand Oaks: Sage; 2001. p. 2-189.

36. Hamelin N, Thaichon P. Consumer motives and impact of western media on the Moroccan luxury buyer. J Retail Consum Serv. 2016;32:164-70. https://doi.org/10.1016/j.jretconser.2016.06.010.

37. Dichter E. Motivating the Japanese consumer. J Int Consum Mark. 1989:1(2): 121-33. https://doi.org/10.1300/J046v01n02_07.

38. Hu W, Grove C. Encountering the Chinese: a guide for Americans. 2nd ed. Yarmouth: Intercultural Press; 1999. p. 80-127.

39. Otnes C, Beltramini RF. Gift-giving and giftgiving: an overview. In: Otnes C, Beltramini RF, editors. Gift-giving: A Research Anthology. Bowling Green: Popular Press; 1996. p. 3-15.

40. Yau OHM, Chan TS, Lau KF. The influence of Chinese cultural values on consumer behavior: a proposed model of gift-purchasing behavior in Hong Kong. J Int Consum Mark. 1999;11(1):97-116. https://doi.org/10.1300/J046v11n01_07.

41. Ho DYF. On the concept of face. Am J Sociol. 1976;81:867-84

42. Chen $Y Q$, Zhu H, Le M, Wu YZ. The effect of face consciousness on consumption of counterfeit luxury goods. Soc Behav Personal Int J. 2014; 42(6):1007-14. https://doi.org/10.2224/sbp.2014.42.6.1007.

43. Li J, Su C. How face influences consumption. Int J Mark Res. 2007:49(2):237-56.

44. Wang JY, Doss S, Guo C, Li W. An investigation of Chinese consumers outshopping motives from a culture perspective. Int J Retail Distrib Manag. 2010;38(6):423-42. https://doi.org/10.1108/09590551011045375.
45. Tai SH. Shopping styles of working Chinese females. J Retail Consum Serv. 2005;12(3):191-203. https://doi.org/10.1016/j.jretconser.2004.06.003.

46. Sun T, Horn M, Merritt D. Values and lifestyles of individualists and collectivists: a study on Chinese, Japanese, British, and US consumers. J Consum Mark. 2004;21(5):318-31. https://doi.org/10.1108/07363760410549140.

47. Jin B, Hye Kang J. "Purchase intention of Chinese consumers toward a US apparel brand: a test of a composite behavior intention model". J Consum Mark. 2011;28(30):187-99. https://doi.org/10.1108/07363761111127617.

48. Piron F. China's changing culture: rural and urban consumers' favorite things. J Consum Mark. 2006;23(6):327-34. https://doi.org/10.1108/07363 760610701869.

49. Moser AK. Thinking green, buying green? Drivers of pro-environmental purchasing behavior. J Consum Mark. 2015;32(3):167-75. https://doi.org/1 0.1108/JCM-10-2014-1179.

50. Roetz H. Chinese 'unity of man and nature': reality or myth? In: Nature, Environment and Culture in East Asia. Brill; 2013. p. 23-39.

51. Chan RY, Lau LB. Antecedents of green purchases: a survey in China. J Consum Mark. 2000;17(4):338-57. https://doi.org/10.1108/07363760010335358.

52. Roetz H. Confucian ethics of the axial age: A reconstruction under the aspect of the breakthrough toward postconventional thinking. Suny Press. 1993.

53. Chen X. Daoism and environment protection, in the dialogue of cultural traditions: a global perspective. Istanbul. 2003.

54. Wang $L$, Juslin $H$. The impact of Chinese culture on corporate social responsibility: The harmony approach. J Bus Ethics. 2009:88(3):433-51.

55. Minton EA, Kahle LR. Belief systems, religion, and behavioral economics: Marketing in multicultural environments. New York: Business Expert Press; 2013.

56. Joy A. Gift giving in Hong Kong and the continuum of social ties. J Consum Res. 2001;28(2):239-56. https://doi.org/10.1086/322900.

57. Qian W, Abdur Razzaque M, Ah Keng K. Chinese cultural values and giftgiving behavior. J Consum Mark. 2007;24(4):214-28. https://doi.org/10.1108/ 07363760710756002

58. Aung $M$, Zhang $X$, Teng $L$. The evolving gift-giving practices of bicultural consumers. J Consum Mark. 2017:34(1):43-52. https:/doi.org/10.1108/JCM-07-2014-1069.

59. Awuni JA, Du J. Sustainable consumption in Chinese cities: green purchasing intentions of young adults based on the theory of consumption values. Sustain Dev. 2016;24(2):124-35. https://doi.org/10.1002/sd.1613.

60. Lin $\mathrm{PC}$, Huang $\mathrm{YH}$. The influence factors on choice behavior regarding green products based on the theory of consumption values. J Clean Prod. 2012;22(1):11-8. https://doi.org/10.1016/j.jclepro.2011.10.002.

61. Wan M, Chen J, Toppinen A. Consumers' environmental perceptions of children's furniture in China. For Prod J. 2015;65(7/8):996-405. https://doi. org/10.13073/FPJ-D-14-00102.

62. Zhejiang Statistics Bureau. Zhejiang Statistics Yearbook 2017. Hangzhou: Zhejiang Provincial Statistical Bureau; 2017.

63. Shachar R, Erdem T, Cutright KM, Fitzsimons GJ. Brands: The opiate of the nonreligious masses?. Marketing Science. 2011:30(1):92-110.

64. McDougall Gordon HG. The Green Movement in Canada: Implications for Marketing Strategy. J Int Consum Mark. 1993;5(3):69-87.

65. Grunert SC. Everybody seems concerned about the environment: But is this concern reflected in (Danish) consumers' food choice?. ACR European Advances. 1993;1:428-33.

\section{Publisher's Note}

Springer Nature remains neutral with regard to jurisdictional claims in published maps and institutional affiliations.

Ready to submit your research? Choose BMC and benefit from:

- fast, convenient online submission

- thorough peer review by experienced researchers in your field

- rapid publication on acceptance

- support for research data, including large and complex data types

- gold Open Access which fosters wider collaboration and increased citations

- maximum visibility for your research: over $100 \mathrm{M}$ website views per year

At $\mathrm{BMC}$, research is always in progress.

Learn more biomedcentral.com/submissions 